\title{
Production and Marketing of Jute in Katihar District of Bihar: A Constraint Analysis
}

\author{
Subhransu Nayak*, Mukesh Kumar Wadhwani and M. Rahaman \\ Agricultural Economic, Bihar Agricultural University, Sabour-813210, \\ Bhagalpur, Bihar, India \\ *Corresponding author
}

\section{A B S T R A C T}

\begin{tabular}{l}
\hline Key w or d s \\
Golden fibre, \\
$\begin{array}{l}\text { SRSWOR, Garrett } \\
\text { Score }\end{array}$ \\
\hline Article Info \\
$\begin{array}{l}\text { Accepted: } \\
\text { 10 September } 2020 \\
\text { Available Online: } \\
10 \text { October } 2020\end{array}$ \\
\hline
\end{tabular}

The study explored the constraints in production and marketing of jute in Katihar district of Bihar based on a sample of 90 jute growers were selected through SRSWOR Multistage Sampling Technique from two clusters consisting of three villages in each of two blocks namely Kadwa and Mansahi of Katihar District. The data were collected through Survey Method. The Garrett's Ranking Technique was used for ranking of the constraints faced by the sample farmers in production and marketing of jute. The sample consisted of 29 small and marginal farmers (32.33 per cent), 30 semi-medium farmers (33.33 per cent), 21 medium farmers (23.33 per cent) and 10 large farmers (11.11 per cent). Among the major constraint faced by jute growers, shortage of labour (GS: 67.95) was the most important constraint first followed by high cost of labor (GS: 61.94). The other important constraints included high pest and disease incidence and problems of weed, ranked as 3rd and 4th constraint by sample growers with Garrett score of 59.69 and 57.80, respectively. The important marketing constraints of jute were shortage of Government Procurement Centers (GS: .69) followed by unorganized market (GS: 51.53) and lack of remunerative prices for jute (GS: 51.27).

\section{Introduction}

Jute (Corchorus spp.) is also known as 'golden fiber' and is the second most important natural fiber produced in India after cotton (GoI, 2018). There are two important commercial species of jute, namely White jute (Corchorus capsularis) and Tossa jute (Corchorus olitorius). The raw jute fiber is used to make carpet, apparel, composites, decorative, furnishings, sacks, mats, bags, tarpaulins and ropes etc. In current situation many synthetic and non-biodegradable fiber have resulted in growing environmental concern whereas jute as a natural and biodegradable fiber is a boon for the society and will have a greater demand in future. Jute is majorly grown in South-East Asia and 85 per cent of jute produced in the world is mostly concentrated in Ganges region covering both India and Bangladesh. Of the total global production of raw jute (29.4 lakh tones), India ranked first with a share of 49.4 per cent while Bangladesh with 46 percent ranked second. The total production of raw jute in the country was 10.14 million bales 
(1bale $=180 \mathrm{~kg}$ jute fiber) in 2018. It contributed around Rs 7000 crores which is 0.32 per cent of India's total value of agriculture output (CRIJAF, 2019). The export value of jute products in India was Rs 2080 crore (FAO, 2016).

The cultivation of jute in India is mainly confined to the states of West Bengal, Bihar, Assam, Odisha, Meghalaya, Nagaland and Tripura, out of which West Bengal is the leading producer, contributing 75 per cent of total production of the country. Bihar is the second largest producer of jute, with cultivation area of 0.835 lakh hectares and production of 1.11 million bales (raw jute) and productivity of 2393 bales / hectare (DES,2018, Bihar, Patna). The districts of Katihar, Purnea, Saharsa, Supaul and Madhepura are the major jute producing districts of the state. It is reported that the jute growers are not able to harvest optimum yield and also not getting remunerative prices of their produce. In view of this the study was planned to identify the constraints involved in production and marketing of jute in the study area and suggest policy measures for betterment of the farming community.

\section{Status of jute in Bihar}

Bihar is the second largest producer of jute of the country with 0.835 lakh hectares of area, production of 1.11 million bales (raw jute) and productivity of 2393 bales / hectare (DES,2018, Bihar, Patna) after West Bengal. The area, production and productivity of jute from 2008-09 to 2017-18 has been presented in table 1 . The table reveals that area under jute is declining while production and productivity was showing a fluctuating trend in the state. The major jute producing districts of the state are Katihar, Purnea, Saharsa, Supaul and Madhepura. The area, production and productivity of jute in these districts have been presented in Table 2. The shows that
Katihar District had the largest area grown for jute (20638 ha) but in terms of production it was the second with production of 20948 bales of jute. Supaul district was the highest producer of jute with 50670 bales while the productivity of jute was highest (6.64 bales/ha) in Madhepura. The Katihar district was selected for present investigation on the basis of highest area under jute in the state. Further Kadwa and Mansahi blocks of the district were selected on the basis of highest (3869 bales) and lowest (658 bales) production of jute.

\section{Materials and Methods}

The Multistage Sampling Technique was used for selecting both the study area and the sample farmers for the study. The primary data was collected from 90 sample jute growers from six villages consisting of two clusters of three villages each selected from two blocks namely Kadwa and Mansahi of Katihar District of Bihar state. The blocks were selected basis of highest and lowest production of jute. The sample jute growers were selected using Simple Random Sampling without Replacement Method (SRSWOR). The analysis was performed using Garrettt's Ranking Technique.

\section{Garrettt's ranking technique}

In this method, the sample farmers were asked to rank the constraints faced by them in production and marketing of jute separately in order of severity. The rank assigned was converted into percent position, from which Garrettt values were obtained using Garrettt's table. Then Garrettt value obtained from Garrettt's table were multiplied to rank given by individual responses and added together.

The sum value as obtained was divided by total number of respondents'. Thus mean score obtained from each constraint and 
ranked by arranging in descending order. The formula used was as follows;

Percentage Position $=100(\mathrm{Rij}-0.5) / \mathrm{Nj}$ Where, $\mathrm{Rij}=$ Rank for ith item by jth individual and $\mathrm{Nj}=$ No. of items ranked by $\mathrm{jth}$ individual.

\section{Results and Discussion}

The sample jute growers included 32 per cent of marginal \& small farmers (29), 33 per cent semi-medium farmers (30), 23 per cent medium farmers (22) and 11 per cent large farmers (10) and has been presented in table 3 (Fig. 1-4).

Table.1 Area, Production and Productivity of Jute in Bihar (2017-18)

\begin{tabular}{|c|c|c|c|}
\hline Year & Area ('000 ha) & Production ('000 bales) & Productivity (kg/ha) \\
\hline $\mathbf{2 0 0 8 - 0 9}$ & 121 & 971 & $\mathbf{1 3 6 1}$ \\
\hline $\mathbf{2 0 0 9}-10$ & 123 & 1118 & $\mathbf{1 6 3 7}$ \\
\hline $\mathbf{2 0 1 0}-11$ & 127 & 1164 & $\mathbf{1 6 4 2}$ \\
\hline $\mathbf{2 0 1 1 - 1 2}$ & 129 & 1490 & $\mathbf{2 0 7 9}$ \\
\hline $\mathbf{2 0 1 2}-13$ & 123 & 1490 & $\mathbf{2 1 8 0}$ \\
\hline $\mathbf{2 0 1 3 - 1 4}$ & 104 & 1498 & $\mathbf{2 5 7 1}$ \\
\hline $\mathbf{2 0 1 4 - 1 5}$ & 94 & 1418 & $\mathbf{2 6 9 4}$ \\
\hline $\mathbf{2 0 1 5}-16$ & 93 & 1308 & $\mathbf{2 5 0 8}$ \\
\hline $\mathbf{2 0 1 6}-17$ & 91 & 1356 & $\mathbf{2 6 7 1}$ \\
\hline $\mathbf{2 0 1 7}-18$ & $\mathbf{8 3}$ & $\mathbf{1 1 1 0}$ & $\mathbf{2 3 9 3}$ \\
\hline
\end{tabular}

Source- DES, Ministry of Agriculture and Farmer welfare, GoI, New Delhi

Table.2 District-wise Area, Production and Productivity of jute in Bihar (2017-18)

\begin{tabular}{|c|l|l|l|c|}
\hline SI. No. & $\begin{array}{l}\text { Name of } \\
\text { District }\end{array}$ & $\begin{array}{c}\text { Area } \\
\text { (ha) }\end{array}$ & $\begin{array}{c}\text { Production } \\
\text { (bales) }\end{array}$ & $\begin{array}{c}\text { Productivity } \\
\text { (bales/ha) }\end{array}$ \\
\hline $\mathbf{1}$ & Araria & 15693 & 27494 & $\mathbf{1 . 7 5}$ \\
\hline $\mathbf{2}$ & Katihar & 20638 & 20948 & $\mathbf{1 . 0 2}$ \\
\hline $\mathbf{3}$ & Kishanganj & 14977 & 20878 & $\mathbf{1 . 3 9}$ \\
\hline $\mathbf{4}$ & Madhepura & 5536 & 36759 & $\mathbf{6 . 6 4}$ \\
\hline $\mathbf{5}$ & Purnia & 12272 & 42989 & $\mathbf{3 . 5 0}$ \\
\hline $\mathbf{6}$ & Supaul & $\mathbf{1 4 3 5 4}$ & $\mathbf{5 0 6 7 0}$ & $\mathbf{3 . 5 3}$ \\
\hline
\end{tabular}

Source- DES, Ministry of Agriculture and Farmer welfare, GoI, New Delhi

Table.3 Classification of sample Jute Growers

\begin{tabular}{|l|l|c|c|}
\hline Category of Jute Growers & Land holding (ha) & \multicolumn{2}{|c|}{ Number of Farmers } \\
\hline & & Number & Percent \\
\hline Marginal \& Small & Less than 2.00 ha & 29 & $\mathbf{3 2 . 2 2}$ \\
\hline Semi-Medium & $2.00-4.00$ ha & 30 & $\mathbf{3 3 . 3 3}$ \\
\hline Medium & $4.00-10.00$ ha & 21 & $\mathbf{2 3 . 3 3}$ \\
\hline Large & More than 10.00 ha & 10 & $\mathbf{1 1 . 1 1}$ \\
\hline & Total & $\mathbf{9 0}$ & $\mathbf{( 1 0 0 . 0 0 )}$ \\
\hline
\end{tabular}


Table.4 Constraints in production of jute

\begin{tabular}{|c|c|c|c|c|c|c|c|c|c|c|c|}
\hline \multirow{4}{*}{$\begin{array}{l}\mathbf{S} \\
\mathbf{l} \\
\mathbf{N} \\
\mathbf{0}\end{array}$} & \multirow{4}{*}{$\begin{array}{l}\text { Production } \\
\text { Constraints }\end{array}$} & \multicolumn{10}{|c|}{ Category of Jute growers (Number) } \\
\hline & & \multirow{2}{*}{\multicolumn{2}{|c|}{$\begin{array}{l}\text { Marginal \& Small } \\
\quad(\mathrm{n} 1=29)\end{array}$}} & \multirow{2}{*}{\multicolumn{2}{|c|}{$\begin{array}{c}\text { Semi-Medium } \\
(\mathrm{n} 2=30)\end{array}$}} & \multirow{2}{*}{\multicolumn{2}{|c|}{$\begin{array}{r}\text { Medium } \\
(\mathrm{n} 3=21)\end{array}$}} & \multirow{2}{*}{\multicolumn{2}{|c|}{$\begin{array}{l}\text { Large } \\
(\mathrm{n} 4=10)\end{array}$}} & \multirow{2}{*}{\multicolumn{2}{|c|}{$\begin{array}{l}\text { Overall } \\
(n=90)\end{array}$}} \\
\hline & & & & & & & & & & & \\
\hline & & $\begin{array}{l}\text { Garrett } \\
\text { Score }\end{array}$ & Rank & $\begin{array}{l}\text { Garrett } \\
\text { Score }\end{array}$ & Rank & $\begin{array}{l}\text { Garrett } \\
\text { Score }\end{array}$ & Rank & $\begin{array}{l}\text { Garrett } \\
\text { Score }\end{array}$ & Rank & $\begin{array}{l}\text { Garrett } \\
\text { Score }\end{array}$ & Rank \\
\hline 1. & $\begin{array}{l}\text { Irregular Supply of } \\
\text { Inputs }\end{array}$ & 33.46 & 11 & 27.44 & 12 & 34.39 & 11 & 29.091 & 12 & 30.47 & 11 \\
\hline 2. & $\begin{array}{l}\text { Higher Prices } \\
\text { of Inputs }\end{array}$ & 39.25 & 10 & 39.85 & 9 & 42.91 & 8 & 45.27 & 8 & 40.47 & 9 \\
\hline 3. & Shortage of Labour & 71.28 & 2 & 63.82 & 1 & 63.34 & 1 & 69 & 1 & 67.95 & 1 \\
\hline 4. & $\begin{array}{l}\text { High cost of } \\
\text { Labour }\end{array}$ & 73.43 & 1 & 61.02 & 3 & 59.04 & 2 & 64.63 & 2 & 61.94 & 2 \\
\hline 5. & $\begin{array}{l}\text { Scarcity of } \\
\text { Irrigation }\end{array}$ & 15.71 & 13 & 21.67 & 13 & 19.17 & 13 & 13.63 & 13 & 18.03 & 13 \\
\hline 6. & $\begin{array}{l}\text { Water } \\
\text { unavailability during } \\
\text { sowing }\end{array}$ & 28.12 & 12 & 28.02 & 11 & 26.86 & 12 & 30.45 & 11 & 27.35 & 12 \\
\hline 7. & $\begin{array}{l}\text { Water shortage } \\
\text { during Retting }\end{array}$ & 45.71 & 6 & 43.61 & 7 & 43.78 & 7 & 52 & 5 & 45.16 & 6 \\
\hline 8. & $\begin{array}{l}\text { Low quality of Fibre } \\
\text { Produced }\end{array}$ & 48.09 & 5 & 44.05 & 6 & 47.34 & 5 & 48.45 & 6 & 46.08 & 5 \\
\hline 9. & $\begin{array}{l}\text { Lack of good } \\
\text { Varieties for jute }\end{array}$ & 43.21 & 8 & 43.47 & 8 & 45.6 & 6 & 41.18 & 9 & 43.09 & 8 \\
\hline 10. & $\begin{array}{l}\text { High pest and Disease } \\
\text { incidence }\end{array}$ & 55.96 & 4 & 63 & 2 & 49.82 & 4 & 53 & 4 & 59.69 & 3 \\
\hline 11. & $\begin{array}{l}\text { Unavailability of } \\
\text { chemicals / } \\
\text { microbial } \\
\text { consortium }\end{array}$ & 43.09 & 9 & 36.02 & 10 & 36.78 & 10 & 40.36 & 10 & 43.12 & 7 \\
\hline 12. & Problems of weeds & 56.46 & 3 & 57.38 & 4 & 54.95 & 3 & 57.9 & 3 & 57.8 & 4 \\
\hline 13. & $\begin{array}{l}\text { Lack of knowledge } \\
\text { about fibre grades }\end{array}$ & 43.62 & 7 & 44.11 & 5 & 41.82 & 9 & 45.9 & 7 & 38.45 & 10 \\
\hline
\end{tabular}


Table.5 Constraints of Jute Marketing

\begin{tabular}{|c|c|c|c|c|c|c|c|c|c|c|c|}
\hline \multirow{4}{*}{$\begin{array}{c}\text { Sl } \\
\text { No } \\
\cdot\end{array}$} & \multirow{4}{*}{$\begin{array}{l}\text { Marketing } \\
\text { constrains }\end{array}$} & \multicolumn{10}{|c|}{ Category of Jute growers (Number) } \\
\hline & & \multirow{2}{*}{\multicolumn{2}{|c|}{$\begin{array}{l}\text { Marginal and Small } \\
\qquad(\mathrm{n} 1=29)\end{array}$}} & \multirow{2}{*}{\multicolumn{2}{|c|}{$\begin{array}{l}\text { Semi-Medium } \\
\quad(\mathrm{n} 2=30)\end{array}$}} & \multirow{2}{*}{\multicolumn{2}{|c|}{$\begin{array}{l}\text { Medium } \\
(\mathrm{n} 3=21)\end{array}$}} & \multirow{2}{*}{\multicolumn{2}{|c|}{$\begin{array}{l}\text { Large } \\
(\mathrm{n} 4=10)\end{array}$}} & \multirow{2}{*}{\multicolumn{2}{|c|}{$\begin{array}{l}\text { Overall } \\
(n=90)\end{array}$}} \\
\hline & & & & & & & & & & & \\
\hline & & $\begin{array}{l}\text { Garrett } \\
\text { Score }\end{array}$ & Rank & $\begin{array}{l}\text { Garrett } \\
\text { Score }\end{array}$ & Rank & $\begin{array}{l}\text { Garrett } \\
\text { Score }\end{array}$ & Rank & $\begin{array}{c}\text { Garrett } \\
\text { Score }\end{array}$ & Rank & $\begin{array}{l}\text { Garrett } \\
\text { Score }\end{array}$ & Rank \\
\hline 1. & $\begin{array}{l}\text { Lack of } \\
\text { Remunerative } \\
\text { Price for jute }\end{array}$ & 53.81 & 2 & 52.61 & 2 & 45.78 & 5 & 57.54 & 1 & 51.27 & 2 \\
\hline 2. & $\begin{array}{l}\text { Shortage of } \\
\text { government } \\
\text { procurement } \\
\text { centres }\end{array}$ & 55.68 & 1 & 54.73 & 1 & 59.86 & 1 & 56.81 & 3 & 55.69 & 1 \\
\hline 3. & $\begin{array}{l}\text { Low } \\
\text { Bargaining } \\
\text { Power }\end{array}$ & 38.9 & 6 & 38.23 & 6 & 35.73 & 6 & 41 & 6 & 37.41 & 6 \\
\hline 4. & $\begin{array}{l}\text { High } \\
\text { Marketing and } \\
\text { Transportatio } n \\
\text { cost }\end{array}$ & 47.4 & 5 & 45.35 & 5 & 51.6 & 4 & 45.45 & 4 & 46.76 & 5 \\
\hline 5. & $\begin{array}{l}\text { Exploitation of } \\
\text { middle men } \\
\text { involved } \\
\text { in marketing }\end{array}$ & 48.12 & 4 & 46.21 & 4 & 54.69 & 2 & 41.54 & 5 & 47.54 & 4 \\
\hline 6. & $\begin{array}{l}\text { Presence of } \\
\text { cheap } \\
\text { subsidiaries } \\
\text { (Plastic Bags) }\end{array}$ & 24.21 & 7 & 22.61 & 7 & 26.21 & 7 & 21.18 & 7 & 23.12 & 7 \\
\hline 7. & $\begin{array}{l}\text { Unorganized } \\
\text { market }\end{array}$ & 51.03 & 3 & 51.71 & 3 & 52.08 & 3 & 57.36 & 2 & 51.53 & 3 \\
\hline
\end{tabular}


Fig.1 Area, production and productivity of jute in Bihar

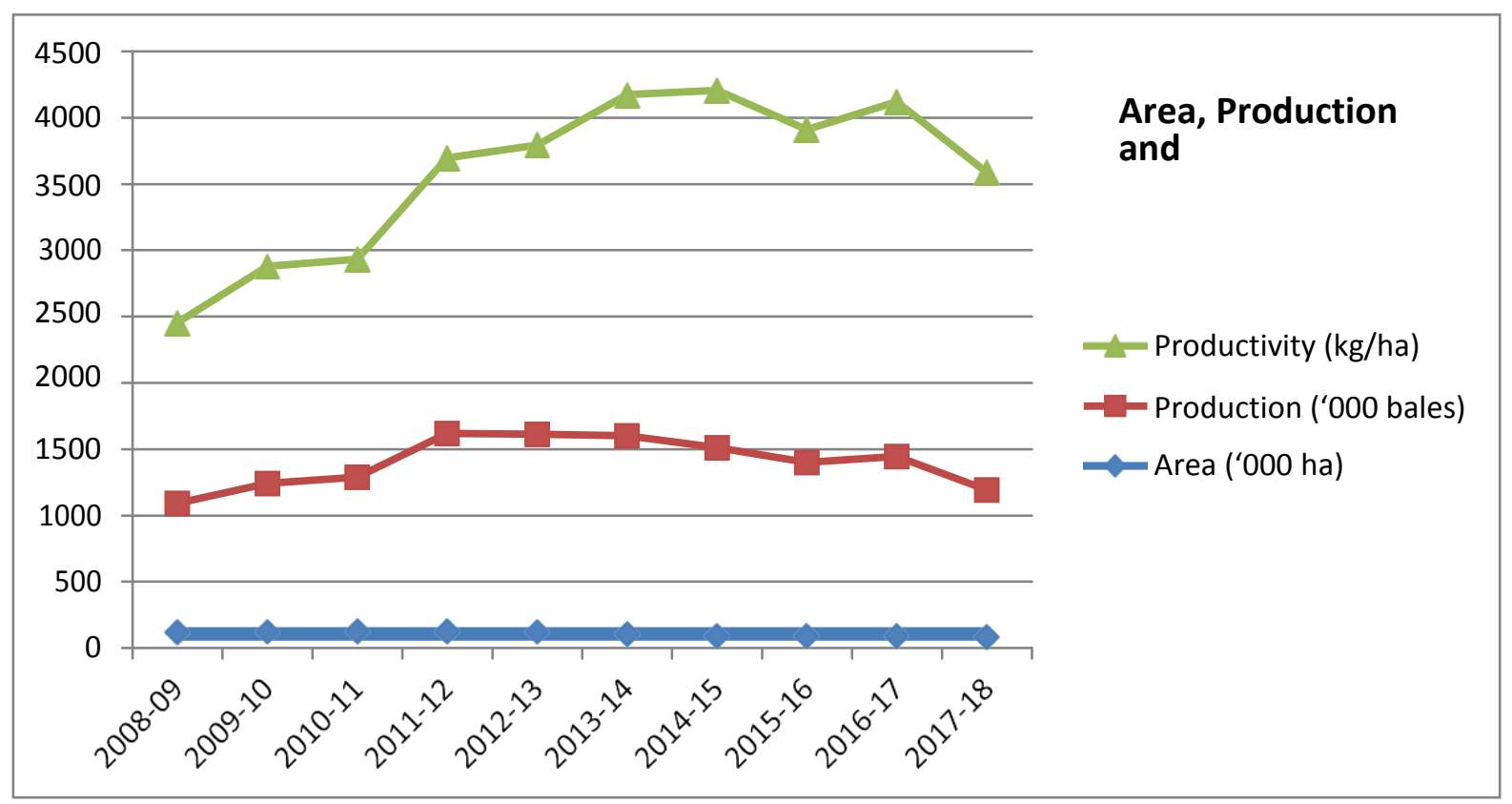

Fig.2 District-wise area, production and productivity of jute in Bihar

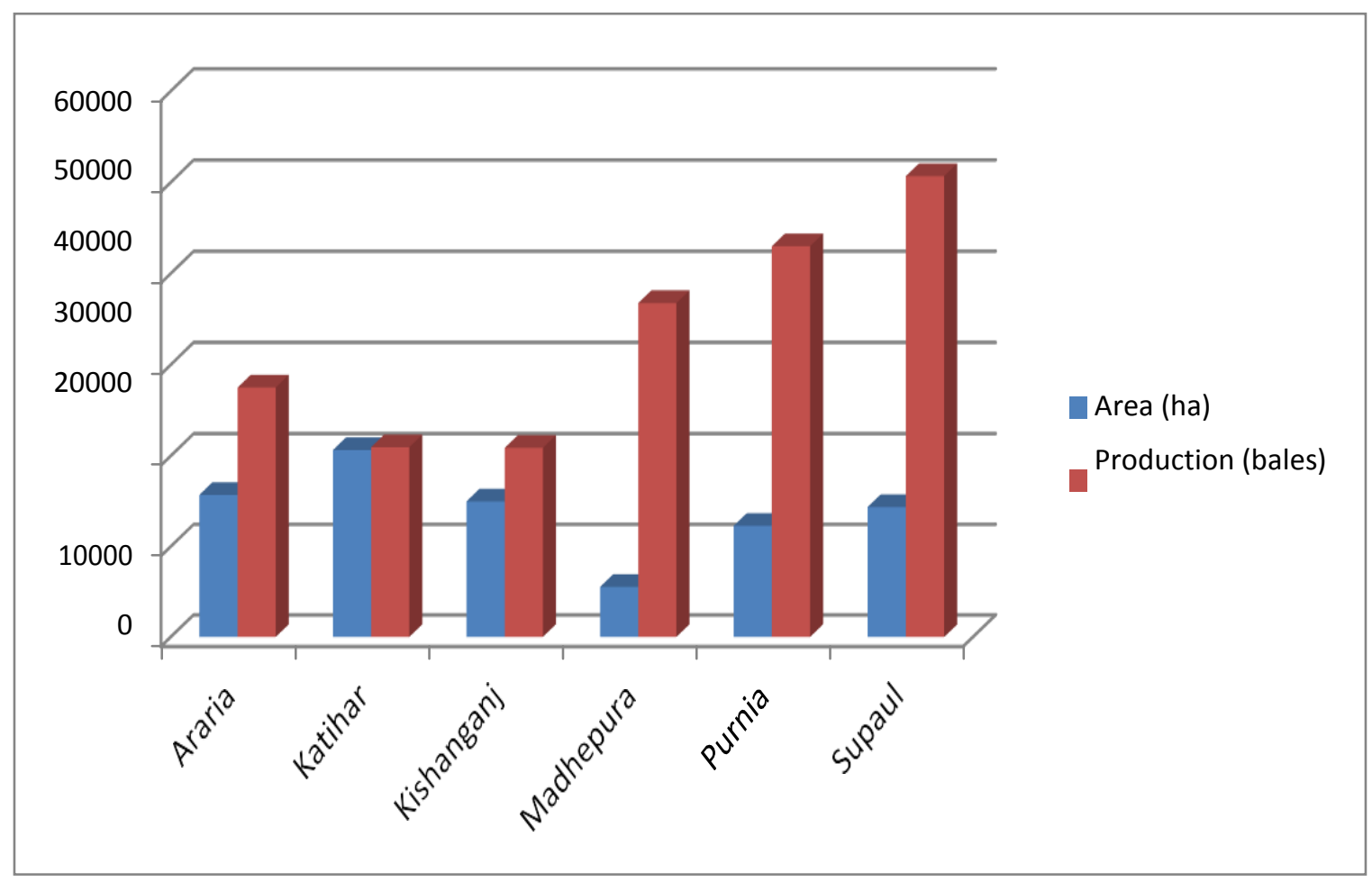


Fig.3 Constraints in production of jute in Bihar

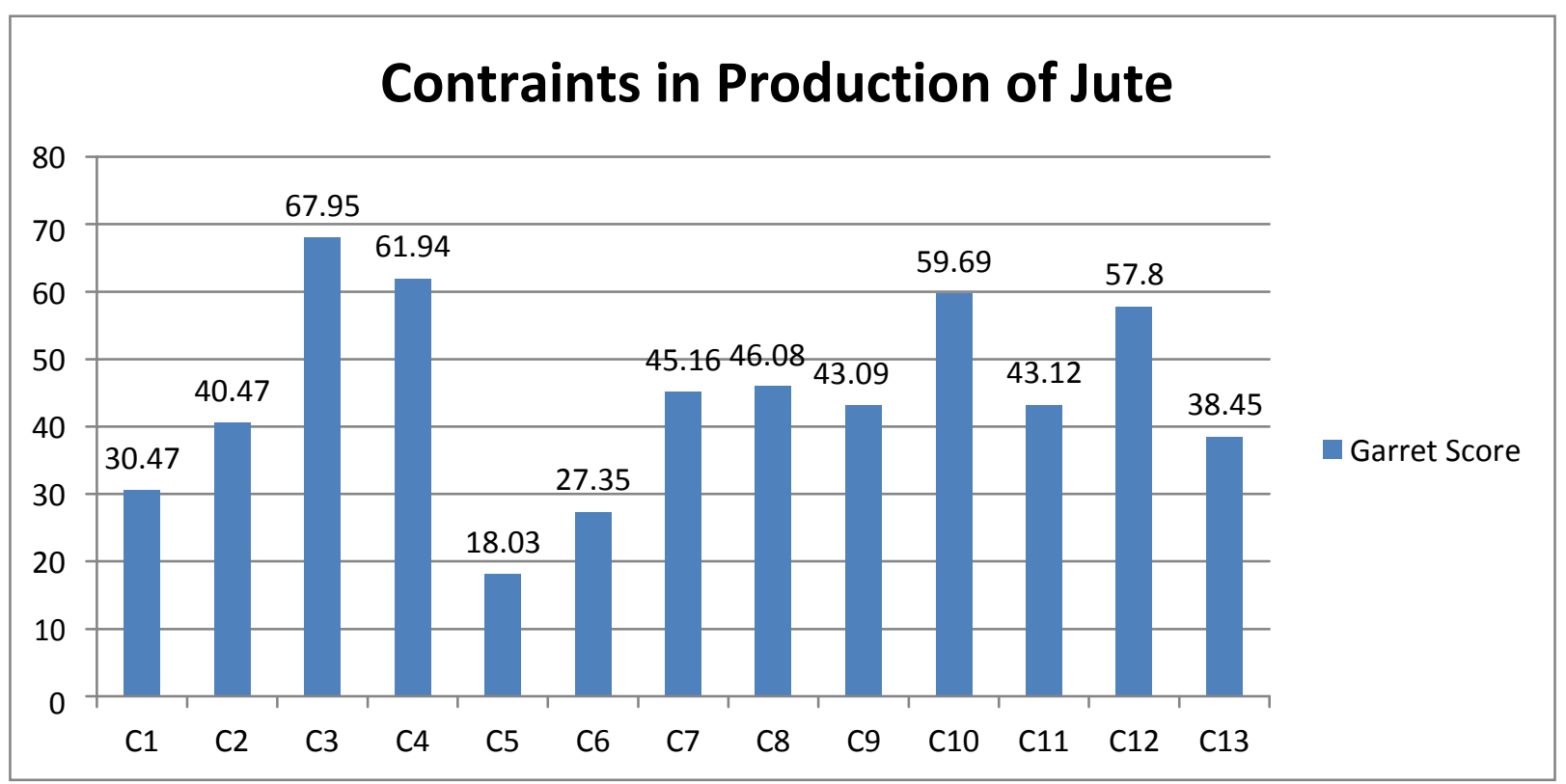

Fig.4 Constraints in marketing of jute in Bihar

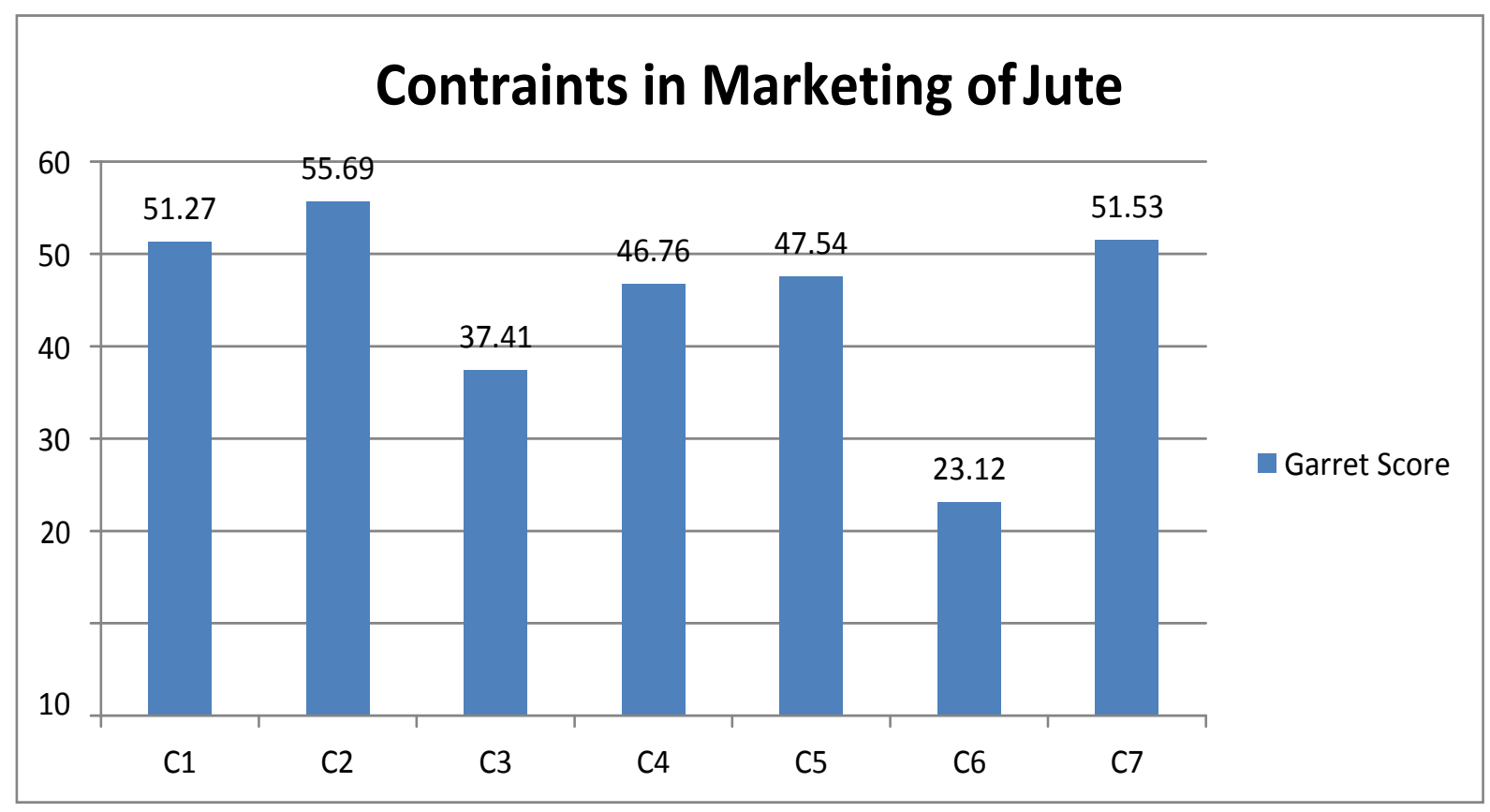




\section{Constraints in production of jute}

The results of constraints faced by sample jute growers in production of jute have been presented in table 4 . The table reveals that high cost of labour (GS: 73.43) and shortage of labour (GS: 71.28) were the two most important constraint in production of jute for marginal and small farmers, which was followed by, problem of weeds (GS:56.46), high pest and disease incidence (GS:55.96) and low quality of fiber produced (GS:48.09). Shortage of labour (GS: 63.82) and high pest and disease incidence (GS: 63.00) were also the two most important constraint for semimedium farmers followed by, high cost of labour (GS: 61.02), problem of weeds (GS: 57.38) and lack of knowledge about fiber grades (GS: 44.11). Same was in case of both medium and large farmers, i.e. the constraint such as shortage of labour and high cost of labour ranked first and second for both of them. On an overall basis also shortage of labour and high cost of labour were the most important constraints with 67.95 and 61.94 Garrett score that clearly reveals that jute is a labour intensive crop and there is shortage of labour in the peak periods. The pest and disease incidence (GS: 59.69) and problem of weeds (GS:57.8) were next two important constraint on overall basis. Low quality of fiber produced (GS:46.08) ranked fifth due to lack of proper agro-techniques followed by sample jute growers during retting while water shortage during retting (GS:45.16) ranked sixth as there was heavy competition for retting among sample farmers during peak period and shortage of water bodies required for retting, unavailability of microbial consortium (GS:43.12) ranked seventh as most of the sample farmers were unaware of the microbial consortium that increases the overall fiber quality and grade and lack of good varieties in jute (GS: 43.09) ranked eighth.
The least concerned constraint were the unavailability of water during sowing (GS: 27.35) and scarcity of irrigation (GS: 18.03) which were ranked twelfth and thirteenth. Lack of knowledge of fiber grades (GS: 38.45) and irregular supply of inputs (GS: 30.47) were ranked as tenth and eleventh constraint in production of jute by the sample farmers.

\section{Constraints in marketing of jute}

The table 5 indicates the results of constraints in marketing of jute. It is revealed that the shortage of Government Procurement Center was considered as the most important constraint and ranked first by all categories of farmers, except large farmers who found lack of remunerative prices for jute as the most important constraint for them. Lack of remunerative prices (GS: 53.81 and 52.61) was the next most important constraint for marginal and small farmers and the semimedium farmers while for medium farmers it was exploitation by middlemen (GS: 54.69) and no organized market (GS: 57.36) for large farmers. The third important constraint for marginal and small, semi-medium and medium farmers was 'no organized market' with Garrett score of 51.03, 51.71 and 52.08 and overall basis also the third most important marketing constraint was 'no organized market'(GS:51.53).

The constraint of least concern in the study area were low bargaining power of farmer (Garrett Score37.41) which ranked sixth and presence of subsidiaries, e.g. plastic bags (Garrett Score: 23.12) that ranked seventh. Most of the farmer received less prices for raw jute due to the exploitation by middlemen in marketing of raw jute (Garrett Score: 47.54) that ranked fourth and high marketing and transportation cost involved during marketing of raw jute ranked fifth (Garrett Score: 46.76) on overall basis. 
It may be concluded from the study that there is a need for proper training of the farmers in adopting the appropriate agro-techniques in production and post-harvest management of the crop for enhancing the production efficiency of the crop. Strengthening the marketing system of raw jute for ensuring remunerative price for raw jute should be given at most priority. The government procurement centers should be increased so as farmers can deposit their produce at the time when prices are very low in market. Production of jute diversified products should be encouraged as they will create huge demand for raw jute in the study area and alternative employment opportunity in the state. The findings will be helpful to jute growers in making aware of the constraints of production and marketing of jute faced by them and will enable them to develop alternate means to overcome these constraints in the study area.

\section{References}

Annual Report (2017-2018) Status of Jute Production in India, ICAR-Central Institute of Jute And Allied Fibre, Barrackpore, West Bengal. 1(2): 9-15.

Ghimire T.B and Thakur N.S (2013) Constraints and Opportunity of Raw Jute Production: A Case Study of eastern Terai Nepal. Agronomy Journal of Nepal 3(1): 177-122.

Hussain M et al., (2002) Problems and Solution Faced by the jute Farmers in a selected area of Bangladesh. Online
Journal of Biological Sciences 2(9): 628-629.

Islam Md, Xiaoying Jian, Uddin Ektear and Bhuiyan F. (2015) Status and Constraints of Jute Cultivation in Bangladesh: An Experience from Upazilas under Chandpur District. Asian Journal of Agriculture and Rural Development, 5(8): 175-186.

Kumari K., Devegowda S.R. and Khuswaha S.(2018) Trend analysis of area production and productivity of jute in India. The Pharma Innovation Journal , 7(12): 58-62.

Shamna A., Jha S.K., Chakraborty A.K. and Kumar S. (2017) Jute Production: The need for linkage among research, farmer and industries in West Bengal. Current Journal of Applied Science and Technology, 25(3):1-6.

Sheheli S. and Roy B. (2014) Constraints and Opportunities of Raw Jute Production: A household Level Analysis in Bangladesh, Progressive Agriculture, 25(1): 38-46.

Status of Raw jute in India (2014), Directorate of Jute Development, GoI, 2(27): 12-46.

Schemes and Measures to Strengthen Jute Sector (2017), Press Information Bureau, Ministry of Textile, GoI, 7(12): 58-62.

www.nirjaft/publication/vision

www.asiajute.com/

History Www.jute.com/statistics

\section{How to cite this article:}

Subhransu Nayak, Mukesh Kumar Wadhwani and Rahaman, M. 2020. Production and Marketing of Jute in Katihar District of Bihar: A Constraint Analysis. Int.J.Curr.Microbiol.App.Sci. 9(10): 909-917. doi: https://doi.org/10.20546/ijcmas.2020.910.109 